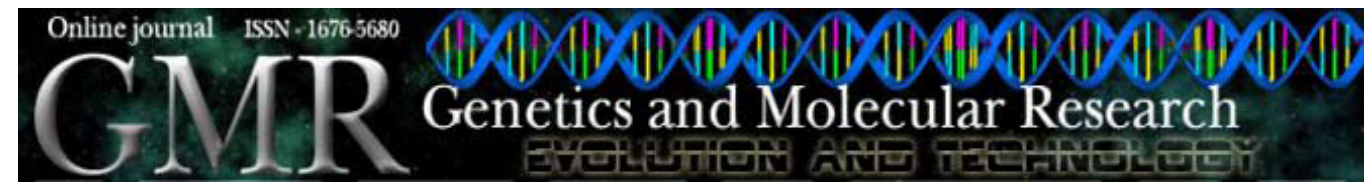

\title{
Genetic mapping of Theobroma cacao (Malvaceae) seedlings of the Parinari series, carriers of the lethal gene Luteus-Pa
}

\author{
B.C. Rehem ${ }^{1}$, A.-A.F. Almeida ${ }^{1}$, R.X. Corrêa ${ }^{1}$, A.S. Gesteira ${ }^{2}$, \\ M.M. Yamada ${ }^{3}$ and R.R. Valle $^{3}$ \\ ${ }^{1}$ Departamento de Ciências Biológicas, \\ Universidade Estadual de Santa Cruz, Ilhéus, BA, Brasil \\ ${ }^{2}$ Empresa Brasileira de Pesquisa Agropecuária - Embrapa, \\ Cruz das Almas, BA, Brasil \\ ${ }^{3}$ Centro de Pesquisas do Cacau, \\ Comissão Executiva do Plano da Lavoura Cacaueira, Itabuna, BA, Brasil \\ Corresponding author: A.-A.F. Almeida \\ E-mail: alexalan.uesc@gmail.com
}

Genet. Mol. Res. 9 (3): 1775-1784 (2010)

Received May 23, 2010

Accepted July 11, 2010

Published September 8, 2010

DOI 10.4238/vol9-3gmr889

\begin{abstract}
The lethal gene ' $L u t e u s-P a$ ' is found in cacao genotypes (Theobroma cacao) of the Parinari (Pa) series, from Peru. Seedlings affected by this gene have yellowing leaves and subsequently die. We mapped this gene based on microsatellite markers and RAPDs, in order to elucidate the inheritance of 'Luteus-Pa' and investigate possible lethal mechanisms. DNA samples of genitors were amplified with 87 SSR and 64 RAPD primers. The SSR primers amplified 65 RAPD primers, giving 179 polymorphic bands. After screening with SSR and RAPD markers, we selected 20 SSR primers, two SSR primers with ESTs and 22 RAPD primers that were polymorphic for genitors $\mathrm{Pa} 30$ and $\mathrm{Pa} 169$. Only two of the 22 RAPD primers and three of the 20 SSR primers were informative and polymorphic in
\end{abstract}


the analysis of the bulk samples of progenies. Among these, primer RAPD E11 produced a band linked to the lethal gene $(38.5 \mathrm{cM})$; none of the SSRs were associated with 'Luteus-Pa'.

Key words: Cacao; Gene expression; Lethal factor; Genetic marker

\section{INTRODUCTION}

Cacao (Theobroma cacao) is a preferably allogamous plant (Cuatrecasas, 1964) native to rain forests. This tree species, under natural conditions, may grow from 20 to $25 \mathrm{~m}$ in height (Lachenaud et al., 1997). Under cultivation, it normally is smaller, reaching $6 \mathrm{~m}$. This species is native to South America (Motamayor et al., 2002); populations can be found in the Amazon and Guiana (Almeida and Valle, 2007). Cacao grows in tropical areas of the Central and South Americas, Asia and Africa (Marita et al., 2001). The fruits of T. cacao are commercially explored for the production of seeds destined to the preparation of cocoa derivatives and sub-products, mainly in its most popular form, chocolate. It may also be manufactured as cosmetics, refined beverages, jellies, ice creams, and juices (Almeida and Valle, 2007).

Various types of markers have been used in genetic-resource characterization, genetic mapping and variability, and phylogeny studies of T. cacao (Lanaud et al., 1999). The availability of highly polymorphic neutral markers, allied to modern statistical procedures, allows the construction of linkage maps for most plant species, even perennials, such as forest and fruit trees (Carneiro and Vieira, 2002). In the case of T. cacao, genetic mapping has been done with molecular markers, comparing segregating populations (Pugh et al., 2004; Faleiro et al., 2006).

Compatibility tests of genotypes of the Parinari $(\mathrm{Pa})$ series from Peru (Yamada et al., 1982) revealed a recessive lethal character, which was named 'Luteus- $P a$ '. This genotypic character was identified for the first time in a Peruvian population; it causes yellowing of the leaves of $\mathrm{Pa} 30, \mathrm{~Pa} 169$ and $\mathrm{Pa} 121$ genotypes of T. cacao. Yellowing is followed by necrosis and death of seedlings, at approximately 30 to 40 days (Almeida et al., 1998). The genes of these genotypes are in heterozygosis. With cross or self-fertilization they segregate at a proportion of 3:1 (Bartley et al., 1983). This gene acts at the reaction center of photosystem 2 (Almeida et al., 1998). The abnormalities are mainly due to the action of simple recessive alleles, probably deriving from specific individual mutations that are characterized by nonpigmentation of the leaves (Bartley, 2005). A similar effect was observed in $\mathrm{F}_{2}$ progenies, resulting from self-fertilization of F1 plants from Pa 121 x SIC 802 and $\mathrm{Pa} 121$ x Pa 169 (Yamada et al., 1982). One fourth of the seedlings originated from these crossings were affected by the mutant gene (Bartley et al., 1983; Bartley, 2005).

The lethal character of gene 'Luteus-Pa' was also evident in seedlings originated from self-fertilization of self-compatible genotypes $\mathrm{Pa} 30$ and $\mathrm{Pa}$ 121. Based on these data, we conclude that various members of the series Pa carry genes responsible for this character's expression; this yellowing and lethal character could be used to help determine relationships between genotypes belonging to this group (Bartley, 2005). However, no molecular markers related to this gene had been found among the genetic maps constructed for T. cacao.

The Pa series is constituted of a number of different genotypes, widely applied for the developing clones and hybrid varieties. This lethal character of gene ' $L u t e u s-P a$ ' may be useful for identifying individuals belonging to the Pa series, constituting a potential genetic marker 
and a tool for paternity tests. In view of the importance of this series for $T$. cacao breeding, we searched for molecular markers that could be used to analyze a population derived from $\mathrm{Pa} 30$ x Pa 169, in order to map the gene 'Luteus- $P a$ '.

\section{MATERIAL AND METHODS}

\section{Plant material and growth conditions}

The Pa 30 and $\mathrm{Pa} 169$ cacao genotypes, used as genitors of the segregating populations in this study, were from the germplasm bank of the Cocoa Research Center (CEPEC) in

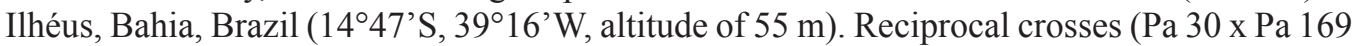
and $\mathrm{Pa} 169 \mathrm{x} \mathrm{Pa} 30$ ) were made and the progenies were grown in a greenhouse. Hybrid seeds, obtained through controlled pollination, were germinated in 2-L polyethylene bags containing organic substrate (peat and shredded pine bark + shredded coconut fiber) at a proportion of 1:1, enriched with macro- and micromineral nutrients (Souza Junior, 2007). Fifteen days after emergence (DAE) of the seedlings, the photosynthetic rate was measured in fully developed and mature leaves, using a portable photosynthetic system LICOR model LI-6400 (Nebraska, USA), to differentiate the mutant seedlings containing the gene 'Luteus-Pa' of the wild type, since the mutant seedlings had negative $\mathrm{CO}_{2}$ exchange and growth was maintained by cotyledonary saccharide and protein reserves (Almeida et al., 1998). Leaf samples were collected, frozen in liquid nitrogen and lyophilized for the genetic mapping studies.

\section{Extraction of DNA from $T$. cacao leaves}

DNA was individually extracted from each sample by means of the CTAB protocol (Doyle and Doyle, 1990), with some changes: $1 \mathrm{M}$ Tris-HCl (final solution $100 \mathrm{mM}$ ), $5 \mathrm{M} \mathrm{NaCl}$ (final solution 1.4 M), 0.5 M EDTA (final solution $20 \mathrm{mM}$ ), $7 \%$ CTAB (final solution 2.8\%), $\beta$ mercaptoethanol (final solution 14.3 M) and 1\% PVP-P. About $200 \mathrm{mg}$ plant tissue (leaves) was transferred to a mortar containing liquid nitrogen. With the help of a pestle, the material was macerated to a fine powder, which was immediately transferred to a 1.5-mL Eppendorf tube. Then, $800 \mu \mathrm{L}$ CTAB buffer was added to each sample, which was homogenized and incubated in a water bath $\left(65^{\circ} \mathrm{C}\right)$ for $1 \mathrm{~h}$, and lightly stirred each $10 \mathrm{~min}$. After incubation, the tubes with the samples were kept at room temperature for $10 \mathrm{~min}$. After that, $700 \mu \mathrm{L}$ chloroform:isoamyl alcohol (24:1) was added to each sample; these were homogenized by tube inversion for 10 $\mathrm{min}$. The tubes were centrifuged for $10 \mathrm{~min}$ at $21,952 \mathrm{~g}$. Addition of isopropanol and centrifugation were repeated twice. The supernatant was then withdrawn and placed into a new Eppendorf tube, to which $700 \mu \mathrm{L}$ frozen isopropanol was added, followed by homogenization of the mixture. After $2 \mathrm{~h}$ at $-20^{\circ} \mathrm{C}$, the sample was centrifuged at $21,952 \mathrm{~g}$ for $15 \mathrm{~min}$ to precipitate the DNA. A white precipitate formed at the bottom of the tube. The liquid part of the tube was discarded and alcohol was carefully added so that the precipitate was not lost. The tubes with the pellets were kept in the dark overnight to allow total evaporation of the alcohol. The DNA was resuspended with $150 \mu \mathrm{L}$ Tris-EDTA (TE) buffer containing RNase at a final concentration of $10 \mathrm{ng} / \mu \mathrm{L}$. After that the tubes with DNA were placed in a water bath for $30 \mathrm{~min}$ at $37^{\circ} \mathrm{C}$.

After extraction and purification, the DNA was quantified by means of electrophoresis on an agarose gel with the following products: $1 \mathrm{X}$ TBE, $1.5 \mathrm{~g}$ agarose, $3.75 \mu \mathrm{L}$ ethidium 
bromide and standard solution $\lambda 50$ and $\lambda 100$ (at the proportion of $1 \mu \mathrm{L} \lambda$ phage DNA at a concentration of $50 \mathrm{ng} / \mu \mathrm{L}$ for $2 \mu \mathrm{L}$ pigment and $1 \mu \mathrm{L} \lambda 100 \mathrm{ng} / \mu \mathrm{L}$ for $2 \mu \mathrm{L}$ pigment) in order to estimate the amount of DNA in each sample.

\section{Amplification of DNA with PCR}

The DNA samples were amplified by means of the random amplified polymorphic DNA (RAPD) technique (Williams et al., 1990), with 64 decamer primers (Operon Technologies, Alameda, CA, USA), as well as with the SSR (single sequence repeat) technique, with 35 microsatellite genomic primers marked with fluorescence (HEX = yellow, TET $=$ green and 6-FAM = blue) and 52 SSR containing ESTs (expressed sequence tags). The reagent concentrations used for the amplification of genomic SSR were those used by Bertolde et al. (2010); the concentrations used for SSRs with ESTs were the same as used by Lima (2007); the concentrations for the RAPDs were those used by Leal et al. (2008), with some modifications. The amplifications with RAPD primers were carried out with the thermal cycler PTC 200 model (MJ Research).

The DNAs of the individuals that constitute the segregating bulks (bulked segregant analysis, BSA) were amplified for the analysis of progeny. These were constituted of the DNA of seven seedlings of the wild-type and seven mutant seedlings (Santos et al., 2007), using polymerase chain reaction (PCR) with microsatellite primers (SSR), with ESTs and T. cacao genomic DNA marked with fluorescence (as above).

The products of the genomic SSR reactions were run on 3\% agarose gel, in order to evaluate the amplification, and then submitted to electrophoresis on polyacrylamide gel in an ABI 377 sequencer. The SSRs with ESTs were evaluated on 6\% polyacrylamide gel stained with $0.2 \% \mathrm{AgNO}_{3}$ solution.

The progeny DNA samples were also amplified by means of the RAPD technique, using the BSA methodology, according to Michelmore et al. (1991). Three microliters of a mixture of bromophenol blue $(0.25 \%)$ and glycerol $(60 \%)$ in water was added to each sample after amplification with RAPD primers. These PCR products were run on a $1.2 \%$ agarose gel stained with ethidium bromide and submersed in TBE buffer ( $90 \mathrm{mM}$ Tris-borate, $1 \mathrm{mM}$ EDTA) and the electrophoretic separation was run approximately $2 \mathrm{~h}$ at 95 volts. At the end of the run, the gels were photographed under ultraviolet light using an image capture system (EDAS 290, Kodak).

\section{Statistical analysis}

The amplified RAPD products were converted into a binary data matrix. The coding adopted was 1 for presence, 0 for absence of the allele and 9 for lost data. The amplified SSR products were converted into a DNA fragment length matrix. The phenotypes of wild-type and mutant plants were coded as 1 and 0 , respectively. The set of data was then recoded according to Lander et al. (1987).

The genetic link analysis was carried out from RAPD and SSR markers and the phenotype related to 'Luteus-Pa' by means of the Mapmaker EXP 3.0 program (Lander et al., 1987). The criteria adopted for this analysis were: LOD $>3.0$ and $\theta<50 \%$, in which: LOD represents the ratio logarithm between the linkage and non-linkage probabilities between the markers and the 'Luteus- $P a^{\prime}$ ' gene and $\theta$ the maximum recombination percentage. 


\section{RESULTS AND DISCUSSION}

Seedlings affected by the gene 'Luteus- $P a$ ' are characterized by negative $\mathrm{CO}_{2}$ exchange (Almeida et al., 1998; Figure 1). Fifteen DAE of the seedlings it was found that the lethal gene 'Luteus- $\mathrm{Pa}$ ' was expressed in $1 / 4$ of the progenies from the crosses $\mathrm{Pa} 30 \times \mathrm{Pa} 169$ and $\mathrm{Pa} 169 \times \mathrm{Pa} 30$, therefore, segregating at a proportion of 3:1. As reported by Almeida et al. (1998), seedling carriers of the lethal allele presented chlorosis and necrotic leaves, followed by death at $60 \mathrm{DAE}$ (Figure 2).

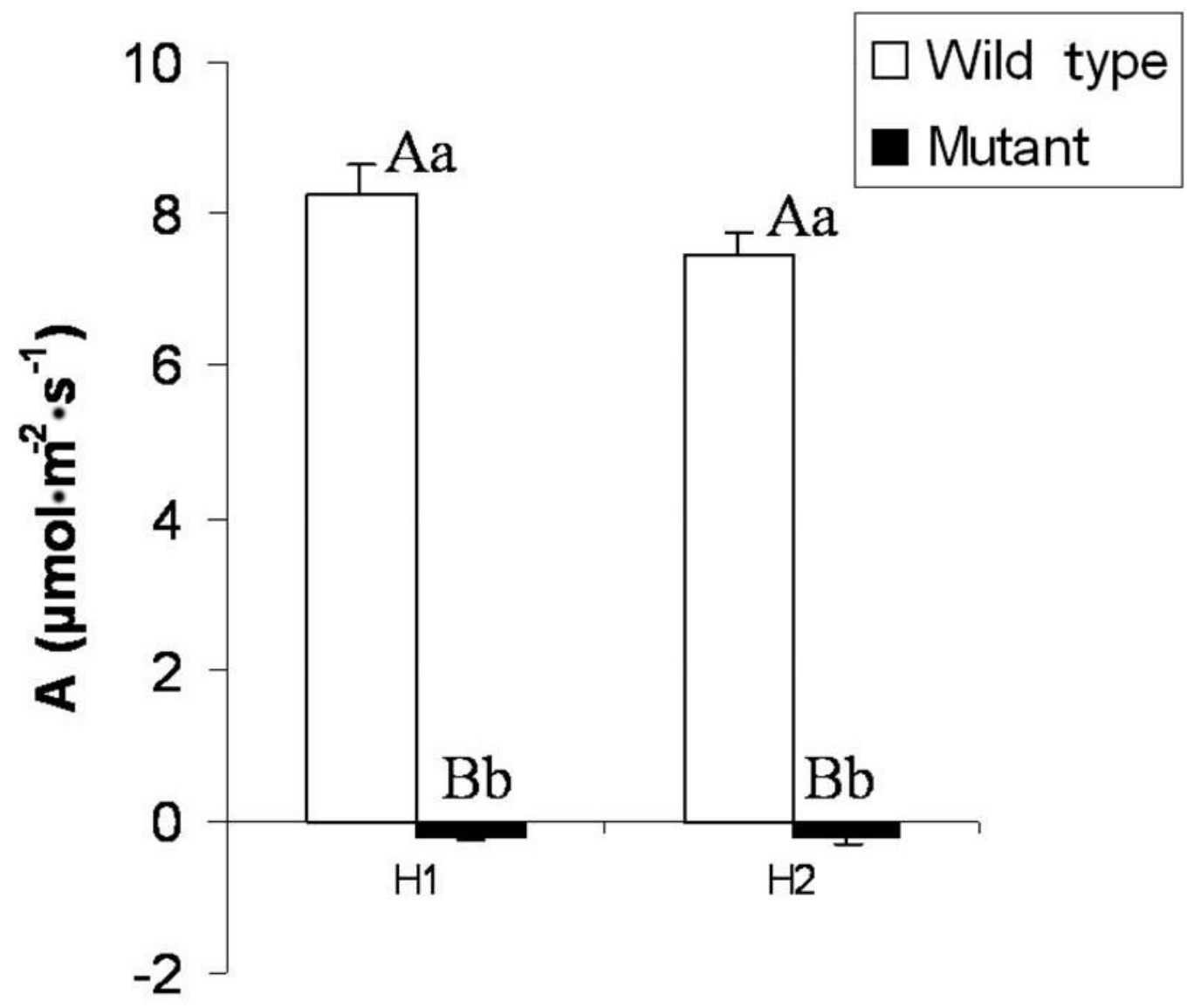

Genotypes

Figure 1. Comparison of the net photosynthetic rates per unit of leaf area (A) in progenies of Theobroma cacao resulting from reciprocal crossings; $\mathrm{H} 1=\mathrm{Pa} 30 \times \mathrm{Pa} 169$ and $\mathrm{H} 2=\mathrm{Pa} 169 \times \mathrm{Pa} 30$. The means represent five replications \pm standard error of the mean. Lower case letters indicate comparisons between crosses and capital letters indicate comparisons between wild-type and mutant seedlings. 

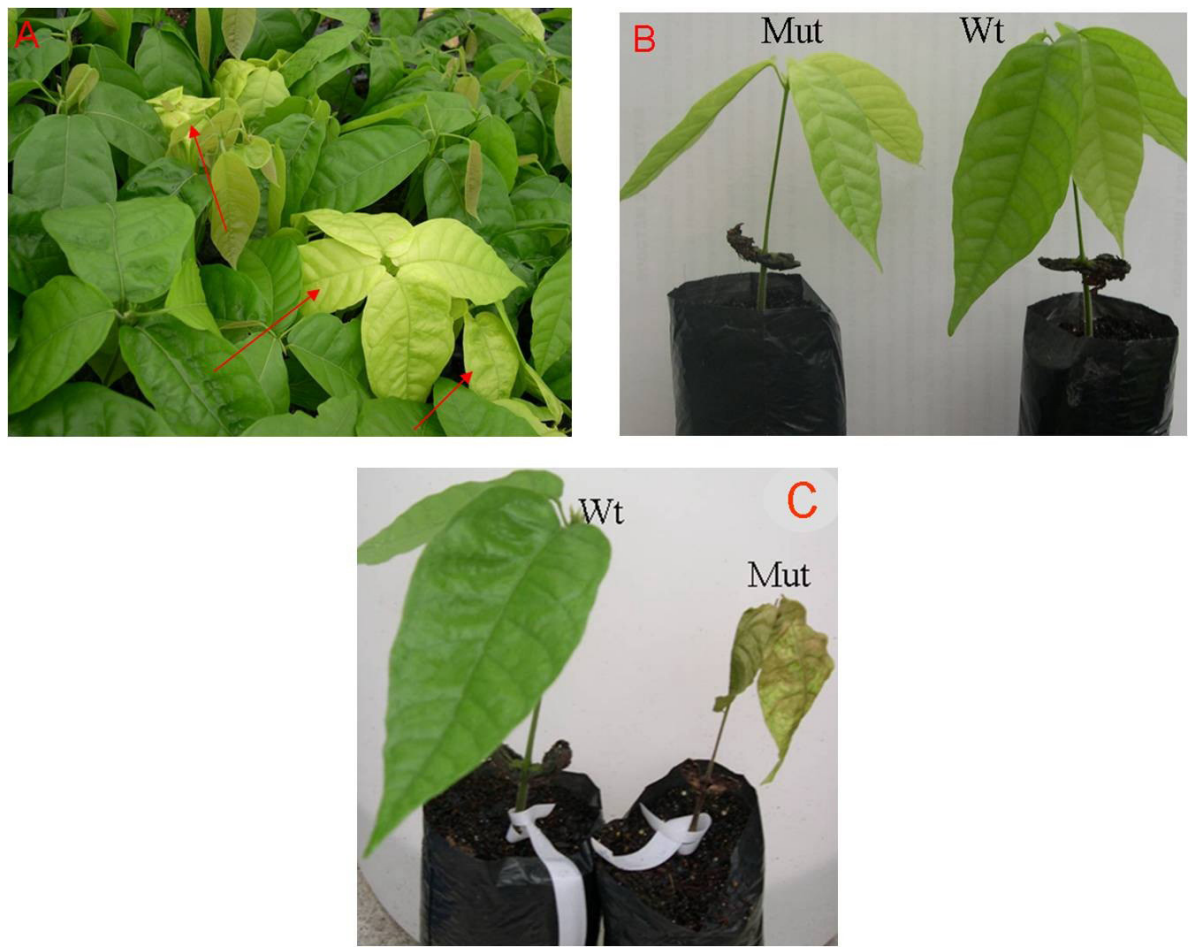

Figure 2. Mutant (Mut) and wild-type (Wt) seedlings of the Theobroma cacao hybrid $\mathrm{Pa} 169 \mathrm{x} \mathrm{Pa} 30$ at 15 (A, B) and 60 (C) days after emergence of seedlings. Note the leaf chlorosis in the mutant seedlings (A - red arrows, B), followed by seedling death $(\mathrm{C})$.

In comparison, the photosynthetic activities of wild-type seedlings resulting from reciprocal crosses did not differ (Figure 1). This proves that inheritance of this gene is simple nuclear and not maternal. The fact that the leaves of mutant seedlings had negative $\mathrm{CO}_{2}$ exchange is due to damage in the PS2 reaction centers of the photosynthesis photochemical phase, resulting in blockage of electron transport, which makes photosynthetic activity impossible (Almeida et al., 1998).

Among the 64 decamer primers tested, 29 (identified by Operon as: A7, A9, A11, A12, A14, A15, A16, A17, A18, B6, B18, D1, D6, D7, D13, D14, D18, D19, E1, E2, E3, E4, E5, E6, E15, E20, H8, H12, and N4) were monomorphic and 13 did not amplify for the genotypes that were evaluated (A3, A4, A5, A6, A8, B11, B17, B20, C3, D2, D3, D4, D5). Among the 179 RAPD bands, 120 were monomorphic in the two genotypes. This predominance of monomorphic bands ( $67 \%$ of the amplified bands) is consistent with the genetic diversity usually reported for T. cacao (Marita et al., 2001; Leal et al., 2008). The genetic similarity coefficient between the two genotypes of the Pa series was 0.67 , the highest value was found by Yamada et al. $(2002,2003)$ for genotypes of this series, based on microsatellite markers.

Among the 22 decamer primers that present polymorphism between $\mathrm{Pa} 30$ and $\mathrm{Pa} 169$, 20 primers, identified by Operon as A20, B3, B4, B5, B9, B12, B18, B19, C2, C6, C10, C11, 
C12, C14, D3, D20, E14, E16, E17, and R19, were monomorphic for DNA bulks, whereas primers E11 and A19 were heteromorphic (Table 1). This low degree of polymorphism between bulks is expected in bulk segregant analysis. Nevertheless, polymorphic and informative bands applicable to localized mapping were found.

\begin{tabular}{|c|c|c|}
\hline \multirow[t]{2}{*}{ Primer } & \multicolumn{2}{|c|}{ Number of fragments } \\
\hline & Amplified & Polymorphic \\
\hline$\overline{\mathrm{A} 19}$ & 7 & 4 \\
\hline A20 & 10 & 4 \\
\hline B3 & 6 & 1 \\
\hline B5 & 8 & 6 \\
\hline B9 & 6 & 5 \\
\hline B12 & 8 & 5 \\
\hline B19 & 5 & 2 \\
\hline $\mathrm{C} 2$ & 5 & 3 \\
\hline C6 & 8 & 1 \\
\hline C11 & 6 & 1 \\
\hline C14 & 9 & 2 \\
\hline D3 & 9 & 1 \\
\hline D20 & 9 & 2 \\
\hline E11 & 8 & 4 \\
\hline E14 & 12 & 1 \\
\hline E16 & 11 & 1 \\
\hline E17 & 7 & 6 \\
\hline R19 & 4 & 1 \\
\hline
\end{tabular}

Of the two primers tested on the population of 200 individuals (150-wild type seedlings and 50 mutant seedlings) only the 1650-bp band generated by primer E11 showed significant genetic linkage with gene 'Luteus- $P a$ '. This band was linked to the lethal gene at a distance of $38.5 \mathrm{cM}$, with a 5.72 LOD score.

When electrophoresis was carried out on a sequencing gel, with the materials from the genitors, only five of the 35 primers (Lanaud et al., 1999; Risterucci et al., 2000) (mTcCIR 6, mTcCIR 8, mTcCIR 12, mTcCIR 13, and mTcCIR 60) were monomorphic for both genotypes (Pa 30 and Pa 169); 20 were polymorphic. The remaining 10 primers (mTcCIR 1, mTcCIR 7, mTcCIR 11, mTcCIR 17, mTcCIR 22, mTcCIR 28, mTcCIR 33, mTcCIR 42, mTcCIR44, and $\mathrm{mTcCIR}$ 57) produced non-informative bands for this cross.

The 35 genomic SSRs tested among the genitors generated 83 alleles, an average of 2.44 alleles per locus, more than observed by Leal et al. (2008) and Bertolde et al. (2010). They used microsatellite markers. According to Bertolde et al. (2010), high-resolution gels, such as the $5 \%$ polyacrylamide gel that we used, make it possible to correctly identify the alleles at each locus, because it allows separation of fragments differing by only $1 \mathrm{bp}$. Also, these markers facilitate this type of analysis, without environmental influence (Lerceteau et al., 1997). One of the main inconveniences occurs when the marker is located far from the gene of interest (Mohan et al., 1997), as we observed.

The mean heterozygosity in the Pa series genotypes was $41.2 \%$. Bertolde et al. (2010) reported that $T$. cacao genotypes have a mean heterozygosity of 40 to $67 \%$. The two genotypes that we evaluated showed $54 \%$ heterozygous loci (Table 2 ). 
in linkage groups 1,6 , and 8 , respectively. The SSR data helped guide the localization search of this gene in T. cacao.

\section{ACKNOWLEDGMENTS}

The authors thank the biological sciences undergraduate student Amanda Santos Silva for helping with this study. We also thank Dr. Fabienne Michele and Dr. Karina Perez Gramacho for permission to test the EST-SSR used in Lima et al. $(2008,2010)$ publications. The authors thank Universidade Estadual de Santa Cruz (UESC), Instituto Biofábrica de Cacau (IBC) and Comissão Executiva do Plano da Lavoura Cacaueira (CEPLAC), for financial support. B.C. Rehem thanks Fundação de Amparo à Pesquisa do Estado da Bahia (FAPESB) and Coordenação de Aperfeiçoamento de Pessoal de Nível Superior (CAPES) for a doctoral fellowship received. Research partially financed by FAPESB and by CNPq.

\section{REFERENCES}

Almeida AAF and Valle RR (2007). Ecophysiology of the cacao tree. Braz. J. Plant Physiol. 19: 425-448.

Almeida AAF, Valle RR and Minar PS (1998). Photosynthesis and associated metabolism during development of a Theobroma cacao hybrid with the lethal factor Luteus-Pa. Photosynthetica 35: 47-60.

Bartley BGD (2005). The Genetics of the Diversity. In: The Genetic Diversity of Cacao and its Utilization. CABI Publishing, Wallingford, 279-297.

Bartley BGD, Yamada MM, Castro GCT and Melo GRP (1983). Genetics of Theobroma cacao: occurrence of lethal factor Luteus Pa in family Parinari. Theobroma 13: 275-278.

Bertolde FZ, De Almeida AA, Correa RX, Gomes FP, et al. (2010). Molecular, physiological and morphological analysis of waterlogging tolerance in clonal genotypes of Theobroma cacao L. Tree Physiol. 30: 56-67.

Carneiro MS and Vieira MLC (2002). Genetic maps in plants. Bragantia 61: 89-100.

Cuatrecasas J (1964). Cacao and its Allies: a Taxonomic Revision of the Genus Theobroma. Bulletin of the United States National Museum. Smithsonian Institution Press, Washington, 35: 379-614.

Doyle JJ and Doyle JL (1990). Isolation of plant DNA from fresh tissue. Focus 12: 13-15.

Faleiro FG, Queiroz VT, Lopes UV, Guimarães CT, et al. (2006). Mapping QTLs for witches' broom (Crinipellis perniciosa) resistance in cacao (Theobroma cacao L.). Euphytica 149: 227-235.

Lachenaud P, Mooleedhar V and Couturier C (1997). Les cacaoyers spontanés de Guyane Nouvelles prospections. Plant Rech. Develop. 4: 25-30.

Lanaud C, Risterucci AM, Pieretti I, Falque M, et al. (1999). Isolation and characterization of microsatellites in Theobroma cacao L. Mol. Ecol. 8: 2141-2143.

Lander ES, Green P, Abrahamson J, Barlow A, et al. (1987). MAPMAKER: an interactive computer package for constructing primary genetic linkage maps of experimental and natural populations. Genomics 1: 174-181.

Leal JB, Santos LM, Santos CAP, Pires JL, et al. (2008). Genetic diversity among farm and germplasm bank accessions of cacao in Bahia, Brazil. Pesq. Agropec. Bras. 43: 851-858.

Lerceteau E, Robert T, Pétiard V and Crouzillat D (1997). Evaluation of the extent of genetic variability among Theobroma cacao accessions using RAPD and RFLP markers. Theor. Appl. Genet. 95: 10-19.

Lima LS (2007). Identificação de Polimorfismo em ESTs de Cacau Associados a Interação Cacau-Moniliophthora perniciosa. Master's of Science thesis, Universidade Estadual de Santa Cruz, Ilhéus.

Lima LS, Gramacho KP, Gesteira AS, Lopes UV, et al. (2008). Characterization of microsatellites from cacao-Moniliophthora perniciosa interaction expressed sequence tags. Mol. Breed. 22: 315-318.

Lima LS, Gramacho KP, Pires JL, Clement D, et al. (2010). Development, characterization, validation, and mapping of SSRs derived from Theobroma cacao L.-Moniliophthora perniciosa interaction ETSs. Tree Genet. Genomes 4: 1-14.

Marita JM, Nienhuis J, Pires JL and Aitken WM (2001). Analysis of genetic diversity in Theobroma cacao with emphasis on witches' broom disease resistance. Crop Sci. 41: 1305-1316.

Michelmore RW, Paran I and Kesseli RV (1991). Identification of markers linked to disease-resistance genes by bulked segregant analysis: a rapid method to detect markers in specific genomic regions by using segregating populations. Proc. 
Natl. Acad. Sci. U. S. A. 88: 9828-9832.

Mohan M, Nair S, Bhagwat A, Krishna TG, et al. (1997). Genome mapping, molecular markers and marker-assisted selection in crop plants. Mol. Breed. 3: 87-103.

Motamayor JC, Risterucci AM, Lopez PA, Ortiz CF, et al. (2002). Cacao domestication I: the origin of the cacao cultivated by the Mayas. Heredity 89: 380-386.

Pugh T, Fouet O, Risterucci AM, Brottier P, et al. (2004). A new cacao linkage map based on codominant markers: development and integration of 201 new microsatellite markers. Theor. Appl. Genet. 108: 1151-1161.

Risterucci AM, Grivet L, N' Goran JAK, Pieretti I, et al. (2000). A high-density linkage map of Theobroma cacao L. Theor. Appl. Genet. 101: 948-955.

Santos RMF, Lopes UV and Bahia RC (2007). Microsatellite markers related to resistance of cocoa tree against witches'-broom. Pesq. Agropec. Bras. 42: 1137-1142.

Souza Júnior JO (2007). Substratos e Adubação para Mudas Clonais de Cacaueiro. Doctoral thesis, Universidade de São Paulo, São Paulo.

Williams JG, Kubelik AR, Livak KJ, Rafalski JA, et al. (1990). DNA polymorphisms amplified by arbitrary primers are useful as genetic markers. Nucleic Acids Res. 18: 6531-6535.

Yamada MM, Bartley BGD, Castro GCT and Melo GRP (1982). Heredity of comparable factor in Theobroma cacao L. I. Phenotypic relations in family Pa (Parinari). Theobroma 12: 163-167.

Yamada MM, Faleiro FG, Lopes UV, Dantas Neto A, et al. (2002). Genetic diversity of cacao accessions of Cepec series by RAPD markers. Agrotrópica 14: 137-140.

Yamada MM, Faleiro FG, Lopes UV, Pires JL, et al. (2003). Genetic variability and heterozygosity of cocoa accessions of Parinari (Pa) population, based on microsatellite markers. Crop Breed. Appl. Biotechnol. 3: 289-296. 